\title{
Advances in Study on Effects of Economic Globalization
}

\author{
Meng Qinghua ${ }^{1}$, Yang Wenchao ${ }^{2}$ \\ ${ }^{1}$ Library, Xuzhou Institute of Technology, Jiangsu, Xuzhou, 221008, China \\ ${ }^{2}$ School of Management, Xuzhou Institute of Technology, Jiangsu, Xuzhou, 221008, China
}

Keywords: connection; cooperation; effects; economic globalization

\begin{abstract}
There are many new notions coming into being with the society developing rapidly. This paper focuses on economic globalization, which plays a very important role in modern society. Economy is the foundation of many other things. The paper introduces its definition, history and its effects, including positive effects and negative effects and gives its opinions.
\end{abstract}

\section{Introduction}

Economic globalization is an important feature of the world economy today, and it is one of the important trends as well. The definition of global economy is: geographically dispersed global economic activity began comprehensive and integrated phenomenon, the main body of the general thought is a multinational company, the specific performance of capital, technology, products and multinational rapid flow or diffusion and multinational company monopoly power of strengthening.

In that passage, General Motors is a typical example. GM buy up parts of bankrupt Daewoo Motor is just one of his going-global strategies and practices. As Charles Darwin noted: Survival of the fittest. So, with the deepening constantly of economic globalization, the enterprises of various countries have to face a new market environment taking globalization as characteristic and management environment.

Nowadays, economic globalization is being referred to more and more. I do not know who first invented the word, but undoubtedly, it is steadily and inexorably becoming more and more common and important. It covers our world so quickly, just like influenza. Take me for an example, just five years ago, I did not know what a computer was, let alone what it can do. But now, I cannot live without my computer, just like I cannot live without my cell phone!

\section{Economic Globalization}

Today, many aspects of our daily life seem to have close connection with other people of different countries. How the outside is going has deep influence on our everyday activities. In terms of me, the globalization is also important for me as how it is for others. And that is the reason why I choose this topic.

First, let's have a good knowledge of its definition. Economic globalization refers to increasing economic interdependence of national economies across the world through a rapid increase in cross-border movement of goods, service, technology and capital. It is the process of increasing economic integration between countries, leading to the emergence of a global marketplace or a single world market.

Depending on the paradigm, globalization can be viewed as either a positive or a negative phenomenon. Economic globalization comprises the globalization of production, markets, competition, technology, and corporations and industries. Whilst economic globalization has been occurring for the last several hundred years (since the emergence of trans-national trade), it has begun to occur at an increased rate over the last 20-30 years. This recent boom has been largely accounted by developed economies integrating with less developed economies, by means of foreign direct investment, the reduction of trade barriers, and in many cases cross border immigration.( From Wikipedia, the free encyclopedia)

Second, we will look back at its history together. International Commodity markets, labor 
markets, and capital markets make up the economy and define economic globalization. Beginning as early as $4000 \mathrm{BC}$, people were trading goats and livestock as a means of money. People residing inan early civilization in Mesopotamiacame up with a tokensystem that was seen as one of the first forms of commodity money. Labor markets consist of workers, employers, wages, income, supply, and demand. Labor markets have been around as long as commodity markets. Labor markets grew out of commodity markets because labor was needed to grow the crops and tend to the livestock. The growth of commodity and labor markets grew into a capital market where companies and governments handle longstanding funds. The process of this cooperation of markets in the economy took thousands of years to become what it is today.

By the early 1900s, it was rare to come across a town that was not influenced by foreign markets-whether it be in labor, prices, or any other policy of business. With advances in boat technology and the inventions of the railroad and telephone, communication with other parts of the country and world was readily available. Towns were no longer limited to what they alone could produce and what the next two towns over would trade with them. People everywhere had the accessibility and resources to obtain goods from the other side of the world. However, these great advances in economic globalization were disrupted by World War I and the Great Depression in the late 1920s. This caused a slowing of world-wide trade and even led to other countries introducing immigration caps.

Third, since we have referred that economic globalization is either a positive or a negative phenomenon, we first look at its positive effects. Well, despite many analysts concern about the inequality gap between developed and developing nations, there is no evidence to suggest that inequality increases as international trade increases. Rather, growth benefits of economic globalization are widely shared. While several globalizers have seen an increase in inequality, most notably China, this increase in inequality is a result of domestic liberalization, restrictions on internal migration, and agricultural policies, rather than a result of international trade. Economic globalization also has helped to decrease poverty around the world. For example,poverty has been reduced as evidenced by a 5.4 percent annual growth in income for the poorest fifth of the population of Malaysia. Even in China, where inequality continues to be a problem, the poorest fifth of the population saw a 3.8 percent annual growth in income. In several countries, those living below the dollar per day poverty threshold declined. In China, the rate decline from 20 to 15 percent, and in Bangladesh the rate dropped from 43 to 36 percent. Well, the third positive effect to be mentioned is the narrowing gap between the rich and the poor.

While many feels that economic globalization increases the gap between rich and poor nations, evidence suggests otherwise. For instance, the growth of globalizers in relation to rich countries suggests that globalizers are narrowing the per capita income gap. China, India, and Bangladesh, who were among the poorest countries in the world twenty years ago, have greatly influenced the narrowing of worldwide inequality due to their economic expansion. Next, let's talk about the negative effects of economic globalization. For example, Because of unbalanced development, these developing countries are lack of high technology. And in this case, these developing countries can't make efficient use of resources during producing. As a result of wasting, resources are being used up and the environment gets worse. Also, with the emergence and development of economic globalization, it will bring a series of bad impacts on many aspects of a nation. Such as shocks to a nation's fine tradition and foreign resources and economic measures may impact different native cultures and may cause assimilation of a native people. As we can see from current situation, economic globalization is an irreversible trend. There is big demand of high-tech and cooperation to develop.

\section{Disadvantages}

Every medal has two sides, Although, there are numbers advantages of economic organizations, so, we should not neglect the disadvantages of economic organizations. At first, the economic risks in economic globalization is unavoidable, as modern science and technology and economic globalization continue to develop, competition among countries has become fiercer than ever before, 
so the financial and economic risks are increasing, and economic security has become a concern for all countries. Such as the economic crisis in 2008 in the world. Therefore, even the economic organization make world become "global village", we should also keep a cool head and should not imitate others mechanically. Besides these, through the economic globalizations and an open-door policy, the erroneous concepts, the lowering of ethical standards, the selfish and individualistic lifestyle or even some harmful cultural products can easily be imported into the country. Additionally, during the process of economic globalization, inequality between developed and developing countries has been increasing and the gap between the rich and the poor has become wider.

\section{Advantages}

The first advantages of economic globalization is that developing countries can attract more foreign investment to increase benefits from the economic development, because the economic globalization brought a worldwide economic and technological development zones and bonded areas and free trade zones and other forms of development of free economic zones. And it will no doubt help to solve the problem of shortage of funds in developing countries. Secondly, the economic globalizations make the worldwide industrial restructuring further, the pace of increase. Developing countries can take advantage of this opportunity with based on reality and focus on the future, and then take the initiative to coordinate the worldwide industrial restructuring and upgrading of domestic industries relationship. Thirdly, there are many advantages for the smaller business owners in developing countries, they can have more opportunities in expanding their companies globally, having more choices when recruiting a workforce. More importantly, they gain an opportunity to target a larger customer base in the world. Lastly, I believe that the economic globalization would also help in promoting international cooperation and peace.

\section{Summary}

Every country including everyone needs cooperation with others only if it and he or she would not want to have development. Sure, nothing is perfect. But when its advantages are much more than its disadvantages, there is no reason we don't accept it. The Internet makes life convenient, so I accept it without any hesitation. The foreign movies are good, I will just like them. The quality of shoes of Nike is reliable, so people would like to spend much money to buy them. So my opinion is that economic globalization is a great phenomenon for the whole world and mankind, also I give its future my best wishes. And in recent years, our nation takes a faster pace to open up to the outside world, and I believe that we will be more open and integrate into world economy. Economic globalization brings us not only a great challenge, but also a great chance to develop. I believe, China's development will be hastened greatly, and China will become the leader of economic globalization of the world if we can strengthen ourselves and take the chance.

\section{References}

[1] Bernstein, Jared. Does inequality prevent economic growth? New York: Business Books UP, 2012

[2] Browning, E.S. “Exorcising Ghosts of Octobers Past.” The Wall Street Journal, October 2007.

[3] Chanda, Nayan. What Is Globalization? New Haven: Yale University UP, 2003.

[4] Chapman, Bruno. Macroeconomic. Boston: Twayne Publisher, 1998.

[5] Li, Hongmei. International Economic Organizations. Shanghai: Engineering Industry UP, 2012.

[6] Reed, Chandler. The Principles of Economy. New York: Columbia UP, 2001.

[7] Roll, Richard. “Is World Economy M\&A Regulation Protectionist?” The Economic Journal, 
April 2007.

[8] Smith, Perry. Contemporary Society: An Introduction to Social Science. New York: Pearson Education, 1972.

[9] Sterling, Steve. Nations. London: Cambridge University Press, 2007. 